\title{
Effect of Chlorantraniliprole on Biochemical and Certain Biomarkers in Various Tissues of Freshwater Fish Labeo rohita(Hamilton)
}

\author{
Nagaraju Bantu, ${ }^{1, *}$, Venkata Rathnamma Vakita ${ }^{2}$, Somaiah Karra $^{3}$ \\ ${ }^{1}$ Department of Biochemistry,Acharya Nagarjuna University,Guntur-522510,A.P,India \\ ${ }^{2}$ Department of Zoology, Acharya Nagarjuna University, Guntur-522510, A.P, India \\ ${ }^{3}$ Department of Environmental Sciences, Acharya Nagarjuna University, Guntur-522510,A.P,India \\ *Corresponding Author:nagaraju.bantu301@gmail.com
}

Copyright (C 2013 Horizon Research Publishing All rights reserved.

\begin{abstract}
Fish were exposed for 15 and 30 days to sublethal concentration of chlorantraniliprole (1/20th LC50) and their biochemical constituents, oxidative stress induction potential was estimated in various tissues of fish Labeo rohita. Protein content of the various tissues like liver, kidney, gills, and muscle decreased by $(41 \%, 37 \%, 63 \%$, and $50 \%$ ) respectively, The maximum reduction of amino acid content in kidney, liver, gills, and muscle of pesticide exposed fish were $(60 \%, 63 \%, 62 \%$, and $51 \%)$ respectively, the same trend was also observe in glycogen and total lipids content. SOD, CAT, GST, Gpx and LPO levels fluctuated in all tissues, compare to control, at sublethal concentration for 15 and 30 days. These findings may be used as biomarker for water pollution.
\end{abstract}

Keywords Sublethal, Oxidative stress, Amino acid, SOD

\section{Introduction}

Pesticides, considered as toxic products, are able to affect all taxonomic vegetal groups depending on physiological and ecological factors [1].Due to urban, industrial and agricultural activities; freshwater sources are dumped with different kinds of chemicals that affect the inhabiting biota. The continuous releases of chemicals impair water quality and become unsuitable for aquatic organisms due to their persistence, bioaccumulation, toxicity and biomagnifications in the food chain [2]. Aquatic ecosystem is the final sink for many chemicals used in industry and agriculture and has become a global problem [3]. Although the emerging pollutants introduced into the aquatic environment by discharges from sewage treatment plants, disposal use and so on [4]. Pesticides are major cause of concern for aquatic environment because of their toxicity, persistency and tendency to accumulate in the organisms [5]. In order to evaluate the adverse effects of these complex chemical mixtures on aquatic organism, there is a worldwide trend to complement chemical and physical parameters with biomarkers in aquatic pollution monitoring [6,7]; the impact of these pesticides on aquatic organisms is due to the movement of pesticides from various diffuse or point sources. Long term exposure of organisms to pesticides means a continuous health hazard for the population. So, human population is at high risk by consuming these toxicated fishes [8]. Pesticides have brought tremendous benefits to mankind by increasing food production and controlling the vectors of man and animal diseases. At the same time use of these pollutants has posed potential health hazards to the life of fishes. The pesticides are posing a great threat to aquatic fauna especially to fishes, which constitute one of the major sources of protein rich food for mankind [9, 10].Chemical pesticides with persistent molecules pose a threat to fish and also to the human population consuming effected fish [11]. Fish are the most important aquatic organisms and are very vulnerable to such environmental stresses [12].Many recent laboratory and field studies have suggested that the measurement of enzymatic activities might be an effective indicator of exposure to chemical pollution [13]; Fish responds to toxicants by altering their enzyme activities and the inhibition of these enzyme activities has been used to indicate the tissue damage [14]. Many xenobiotics, such as pesticides, can produce reactive oxygen species(ROS) via several mechanisms, such as interference in electron transport of reactive intermediates, inactivation of antioxidant enzymes, depletion of non-enzymatic antioxidants and membrane lipid peroxidation[15]; superoxide dismutase, the first enzyme in the line of antioxidant defense, is responsible for catalyzing the conversion of the superoxide ions into water and molecular oxygen via catalase[16].Catalase is a major antioxidant enzyme found in virtually all aerobic organisms. The activity of the enzyme varies in different tissues, being higher in organs with high oxidative potential [17]. 
Biochemical indicators, know as biomarkers, can serve as early warning signs of environmental pollution or stress indication to soil organisms, and can be divided in three classes: exposure biomarkers, effect biomarkers, and susceptibility biomarkers [18]. Biomarkers of exposure are related with cellular or molecular responses indicating an interaction between an organism and a xenobiotic agent [19]. The effectiveness of biomarkers has been demonstrated in several studies on the toxicity of pesticides to fish [20]. The aim of the present study to estimate the biochemical constituents, antioxidant enzymes and lipid peroxidation (LPO) levels in gill, muscle, liver, and kidney of fish Labeo rohita exposed to the insecticide chlorantraniliprole $18.5 \%$ SC (Suspension concentrate).

\section{Materials and Methods}

The common edible fish Labeo rohita is obtained from the local fish farm at Nandivelugu; Guntur District of Andhra Pradesh, India. The fish were brought to the laboratory by using glass aquaria with high oxygen concentration and transferred in to the glass chambers for acclimatization. The length of the fish $7 \pm 8 \mathrm{~cm}$, average body weight $9-10 \mathrm{~g}$. The fish Labeo rohita were acclimatized to the laboratory conditions at $28 \pm 2^{\circ} \mathrm{C}$. The fish were fed daily with commercial fish pellets and allowed to acclimate for 15 days. Water was renewed every day to provide freshwater, rich in oxygen. If mortality exceeds more than $5 \%$ during the acclimatization, the entire batch of fish was discarded. The water used for acclimatization, to conduct the experiments was clear and Un-chlorinated ground water, according to [21]. The pesticide chlorantraniliprole, trade name as (Coragen $\left.{ }^{\circledR}\right)$ was purchased from local pesticide market in Guntur. The containers used for the test media of 35 liters capacity, where in each test five containers were used and in each container 30 fish were maintained, the experiments were conducted to determine the toxicity in different concentrations of the toxicant for $24 \mathrm{~h}, 48 \mathrm{~h}, 72 \mathrm{~h}$ and $96 \mathrm{~h}$ in semi- static system [22] to calculate the $\mathrm{LC}_{50}$ values. The $96 \mathrm{~h}$ $\mathrm{LC}_{50}$ value of chlorantraniliprole to the fish Labeo rohita was found to be $12.748 \mathrm{mg} / \mathrm{l}$. The fish were exposed for 15 and 30 days to sublethal concentration $\left(1 / 20^{\text {th }} 96 \mathrm{~h}\right.$ of $\mathrm{LC}_{50}$ i.e. $0.637 \mathrm{mg} / \mathrm{l})$ of chlorantraniliprole $18.5 \%$ suspension concentrate (SC) insecticide. At the end of 15 and 30 days of exposure, the tissues such as liver, muscle, kidney, brain, and gill were collected by dissecting the animal and stored at $20^{\circ} \mathrm{C}$, for biochemical studies.

\subsection{Biochemical Studies}

The protein content of the sample was determined according to the method of [23] using crystalline bovine serum albumin standard. The glycogen by [24] for estimation of the glycogen glucose was used as standard. The free amino acids were determined by ninhydrin method [25]. The total lipids were extracted based on the procedure of [26].Enzyme assay; the activity levels of SOD, CAT, Gpx,
GST, and lipid peroxidation (LPO) were determined spectrophotometrically according to the standard methods. Catalase activity was estimated by the method [27], lipid peroxidation by [28], and SOD activity by [29].Glutathione peroxidase (GPx) activity by the non- enzymatic method [30]. Glutathione S-tranferase (GST) activity was determined by the method of [31].

\subsection{Data Analysis}

All enzymatic assays were performed in triplicate. Mean and standard deviation (SD) values were determined for all the parameters and the results were expressed as mean $\pm \mathrm{S} \mathrm{D}$ $(n=6)$ from assay. The data were analyzed employing analysis of one-way variance (ANOVA) followed by a Multiple Comparison Test (MCT) using Statistical Program for Social Sciences (SPSS); 20.0v and Minitab15.0v. P -values below 0.05 were regarded as significant.

\section{Results}

In the present study fish were exposed to sublethal concentration $\left(1 / 20^{\text {th }} 96 \mathrm{~h}\right.$ of $\left.\mathrm{LC}_{50}\right)$ of insecticide chlorantraniliprole for period of 15 and 30 days, the protein, glycogen, free amino acids and total lipids was significantly decreased when compared to the control.(Table 1 and 2.)

Table 1. Variation in the biochemical constituents of liver, kidney, gills, and muscle of Labeo rohita for 15 days

\begin{tabular}{|c|c|c|c|}
\hline Tissues & control & $\begin{array}{c}\text { Sublethal } 15 \\
\text { days } \\
\text { exposure }\end{array}$ & $\begin{array}{l}\text { Biochemical constituents } \\
\text { expressed in } \mathrm{mg} / \mathrm{g} \text { wet } \\
\text { weight of the tissue }\end{array}$ \\
\hline muscle & $\begin{array}{c}184.41 \pm 0.3 \\
47.32 \pm 0.04 \\
13.88 \pm 0.04 \\
185.71 \pm 3.49 \\
\end{array}$ & $\begin{array}{c}126.52 \pm 0.29^{\mathrm{c}} \\
24.21 \pm 0.08^{\mathrm{b}} \\
10.92 \pm 0.02^{\mathrm{c}} \\
168.16 \pm 4.1^{\mathrm{a}} \\
\end{array}$ & $\begin{array}{c}\text { proteins } \\
\text { Glycogen } \\
\text { Free amino acids } \\
\text { Total lipids } \\
\end{array}$ \\
\hline liver & $\begin{array}{c}153.46 \pm 0.03 \\
38.94 \pm 0.05 \\
13.84 \pm 0.02 \\
87.28 \pm 2.29\end{array}$ & $\begin{array}{c}59.36 \pm 8.30^{\mathrm{b}} \\
31.56 \pm 0.32^{\mathrm{d}} \\
10.15 \pm 0.03^{\mathrm{a}} \\
64.42 \pm .08^{\mathrm{d}}\end{array}$ & $\begin{array}{l}\text { proteins } \\
\text { Glycogen } \\
\text { Free amino acids } \\
\text { Total lipids }\end{array}$ \\
\hline kidney & $\begin{array}{c}149.74 \pm 0.04 \\
34.58 \pm 0.08 \\
9.61 \pm 0.09 \\
79.14 \pm 2.84 \\
\end{array}$ & $\begin{array}{c}65 \pm 0.03^{\mathrm{a}} \\
28.54 \pm 0.04^{\mathrm{a}} \\
8.74 \pm 0.06^{\mathrm{d}} \\
75.18 \pm 8.24^{\mathrm{b}} \\
\end{array}$ & $\begin{array}{c}\text { proteins } \\
\text { Glycogen } \\
\text { Free amino acids } \\
\text { Total lipids } \\
\end{array}$ \\
\hline gills & $\begin{array}{c}37.31 \pm 0.3 \\
8.75 \pm 0.08 \\
11.21 \pm 0.04 \\
85.42 \pm 3.62 \\
\end{array}$ & $\begin{array}{c}29.39 \pm 0.04^{\mathrm{a}} \\
7.59 \pm 0.03^{\mathrm{a}} \\
9.92 \pm 0.03^{\mathrm{c}} \\
74.72 \pm 0.29^{\mathrm{d}}\end{array}$ & $\begin{array}{c}\text { Proteins } \\
\text { Glycogen } \\
\text { Free amino acids } \\
\text { Total lipids } \\
\end{array}$ \\
\hline
\end{tabular}

Data represents means $\pm \mathrm{SD}$ of six individual values; different letters indicate significant differences between the groups at sublethal concentration for 15 days.

a) $\quad p \leq 0.05$ denotes significant when compared with control

b) $\quad p \leq 0.02$ denotes significant when compared with control

c) $\quad p \leq 0.01$ denotes significant when compared with control

d) $p \leq 0.005$ denotes significant when compared with control 


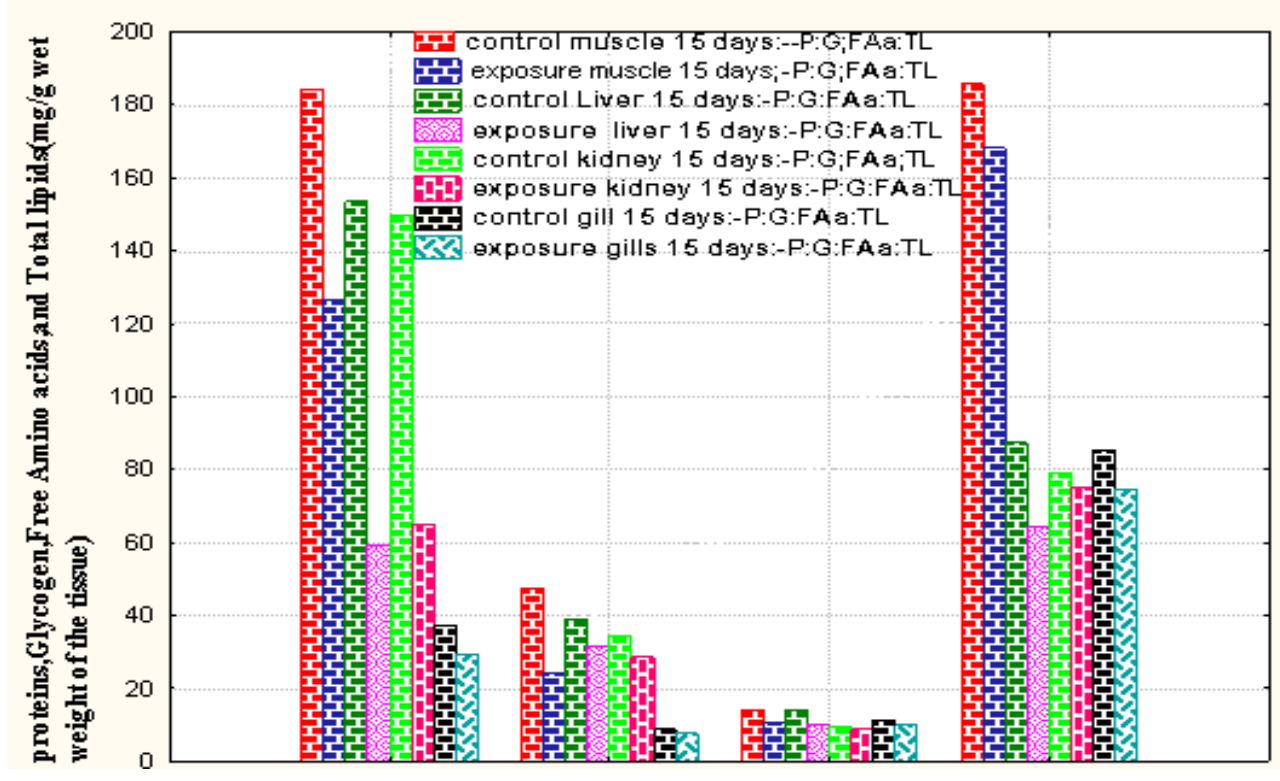

Days of Exposure 15

Figure 1. Changes in the biochemical constituents(Proteins(P), Glycogen(G),Free amino acids(FAa), and Total lipids(Tl) of fish L.rohita exposed to sublethal concentration of chlorantraniliprole for 15 days. Bars represent means and vertical lines the SD of six individual observations

Table 2. Variation in the biochemical constituents of liver, kidney, gills, and muscle of Labeo rohita for 30 days

\begin{tabular}{|c|c|c|c|}
\hline Tissues & control & $\begin{array}{l}\text { Sublethal } 30 \text { days } \\
\text { exposure }\end{array}$ & $\begin{array}{l}\text { Biochemical constituents expressed in } \mathrm{mg} / \mathrm{g} \text { wet weight } \\
\text { of the tissue }\end{array}$ \\
\hline muscle & $\begin{array}{c}139.61 \pm 0.04 \\
45.36 .47 \pm 0.05 \\
11.20 \pm 0.06 \\
174.99 \pm 4.29\end{array}$ & $\begin{array}{c}78.63 \pm 0.3^{\mathrm{a}} \\
22.99 \pm 0.06^{\mathrm{b}} \\
8.69 \pm 0.006^{\mathrm{d}} \\
122.37 \pm 2.61^{\mathrm{b}}\end{array}$ & $\begin{array}{c}\text { proteins } \\
\text { Glycogen } \\
\text { Free amino acids } \\
\text { Total lipids }\end{array}$ \\
\hline liver & $\begin{array}{c}156.38 \pm 0.03 \\
43.94 \pm 0.08 \\
10.37 \pm 0.05 \\
124.51 \pm 6.32\end{array}$ & $\begin{array}{c}87.35 \pm 2.36^{\mathrm{b}} \\
38.44 \pm 0.5^{\mathrm{a}} \\
8.41 \pm 0.08^{\mathrm{c}} \\
69.32 \pm 3.64^{\mathrm{d}}\end{array}$ & $\begin{array}{c}\text { proteins } \\
\text { Glycogen } \\
\text { Free amino acids } \\
\text { Total lipids }\end{array}$ \\
\hline kidney & $\begin{array}{c}151.69 \pm 0.05 \\
39.87 \pm 0.03 \\
8.34 \pm 0.06 \\
98.32 \pm 3.91\end{array}$ & $\begin{array}{c}62.25 \pm 0.03^{\mathrm{b}} \\
29.22 \pm 0.06^{\mathrm{c}} \\
5.18 \pm 0.9^{\mathrm{c}} \\
32.25 \pm 0.49^{\mathrm{d}}\end{array}$ & $\begin{array}{c}\text { proteins } \\
\text { Glycogen } \\
\text { Free amino acids } \\
\text { Total lipids }\end{array}$ \\
\hline gills & $\begin{array}{c}41.75 \pm 0.21 \\
16.44 \pm 0.06 \\
8.99 \pm 0.03 \\
85.31 \pm 8.71\end{array}$ & $\begin{array}{c}29.63 \pm 2.94^{\mathrm{c}} \\
6.57 \pm 0.08^{\mathrm{a}} \\
5.36 \pm 0.02^{\mathrm{d}} \\
69.15 \pm 0.8^{\mathrm{a}}\end{array}$ & $\begin{array}{c}\text { proteins } \\
\text { Glycogen } \\
\text { Free amino acids } \\
\text { Total lipids }\end{array}$ \\
\hline
\end{tabular}

Data represents means $\pm \mathrm{SD}$ of six individual values; different letters indicate significant differences between the groups at sublethal concentration for 30 days

a) $p \leq 0.01$ denotes significant when compared with control

b) $p \leq 0.02$ denotes significant when compared with control

c) $p \leq 0.005$ denotes significant when compared with control

d) $\quad p \leq 0.001$ denotes significant when compared with control 


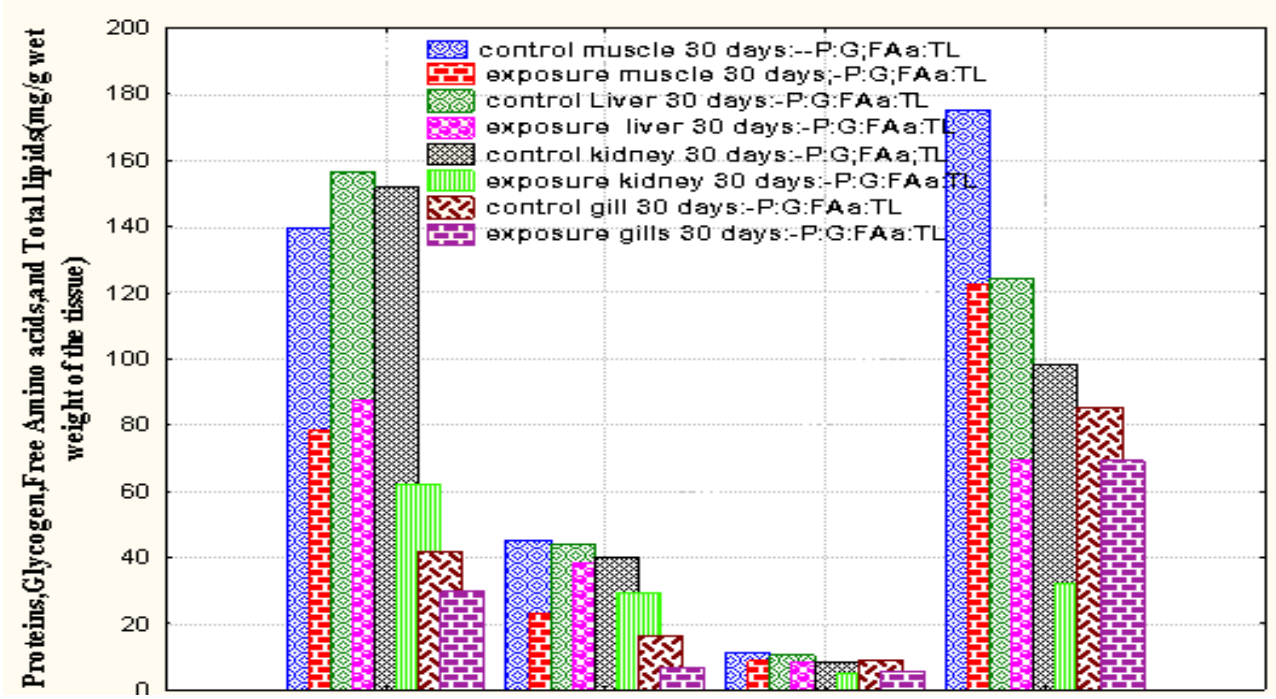

Days of Exposure 30

Figure 2. Changes in the biochemical constituents(Proteins(P),Glycogen(G),Free amino acids(FAa), and Total lipids(TL) of fish L.rohita exposed to sublethal concentration of chlorantraniliprole for 30 days. Bars represent means and vertical lines the SD of six individual observations

Table 3. SOD activity (Units mg protein ${ }^{-1}$ ) in gill, liver, kidney and muscle of control and treated fish L.rohita

\begin{tabular}{|c|c|c|c|l|}
\hline Tissues & Control 15days & 15 days exposed & Control 30days & 30 days exposed \\
\hline gill & $0.71 \pm 0.03$ & $0.85 \pm 0.04(19.9 \%)$ & $0.57 \pm 0.03$ & $0.76 \pm 0.06(33.33 \%)$ \\
\hline liver & $0.62 \pm 0.06$ & $0.84 \pm 0.07(35.2 \%)$ & $0.81 \pm 0.04$ & $0.99 \pm 0.04(59.67 \%)$ \\
\hline kidney & $0.69 \pm 0.05$ & $0.84 \pm 0.1(21.7 \%)$ & $0.54 \pm 0.04$ & $0.78 \pm 0.05(44.44 \%)$ \\
\hline muscle & $0.77 \pm 0.01$ & $0.85 \pm 0.1(10.38 \%)$ & $0.58 \pm 0.08$ & $0.79 \pm 0.17(36.20 \%)$ \\
\hline
\end{tabular}

Data are means $\pm \mathrm{SD}$ of six individual values; significant at $p \leq 0.05$

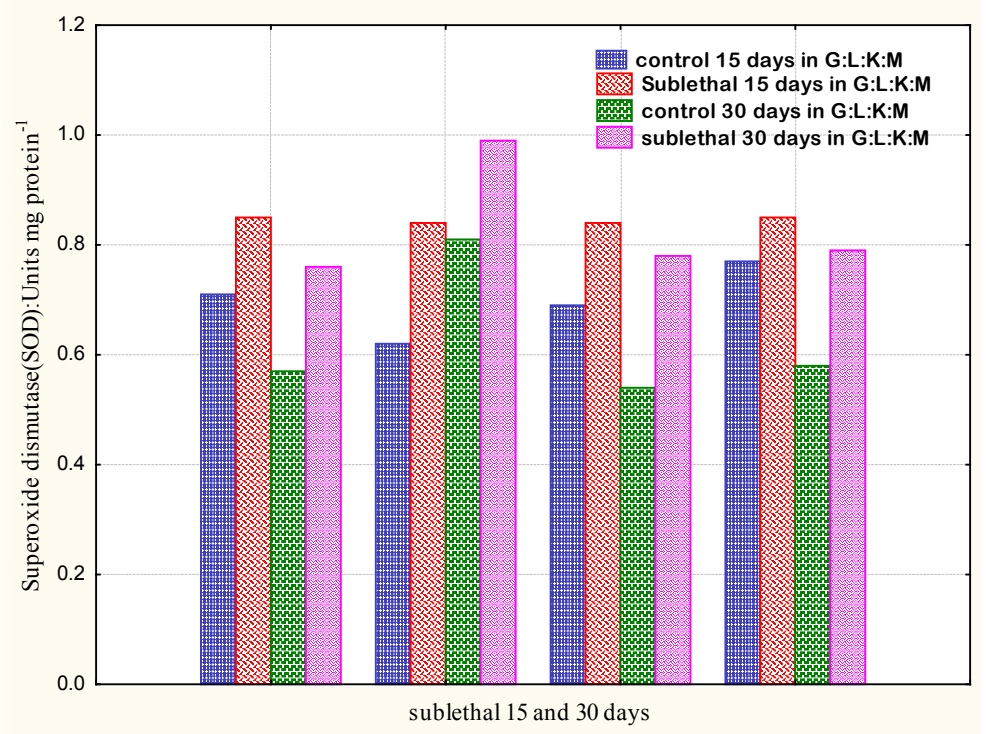

Figure 3. Activity of SOD in gill, liver, kidney and muscle of fish L.rohita exposed to sublethal concentration of chlorantraniliprole for 15 and 30 days. Bars represent means and vertical lines the SD of six individual observations

\subsection{Antioxidant Enzymes}

3.1.1. Superoxide Dismutase (SOD) 
Activities of superoxide dismutase in fish L.rohita exposed to sublethal concentration of chlorantraniliprole were shown in Table 3 and figure 3.All the levels were compared with control and found to be significantly different. Chlorantraniliprole exposure showed overall increase in several antioxidant enzymes. The days of exposure, concentration of pesticide increased the amount of SOD also increased, and maximum increased in liver i.e. (35.2\%), minimum in muscle (10.38) for 15 days. In 30 days of exposure the maximum increased in $(59.67 \%)$ in liver, minimum in $(33.33 \%)$ in gill.

\subsubsection{Catalase (CAT)}

Activities of catalase in fish L.rohita were shown in Table 4 and figure 4, all the levels were compared with control and found to be significantly different. The days of exposure, concentration of pesticide increased, the amount of SOD also increased maximum increased in liver (58.62\%), minimum increased in muscle (14.28\%) for 15 days. In 30 days of exposure the maximum increased in $(81.63 \%)$ in liver, minimum in $(31.11 \%)$ in gill.

Table 4. CAT activity (nmol of $\mathrm{H}_{2} \mathrm{O}_{2}$ decomposed $\min ^{-1}$ (mg protein) ${ }^{-1}$ ) in gill, liver, kidney and muscle of control and treated fish L.rohita

\begin{tabular}{|c|c|c|c|c|}
\hline Tissues & Control 15 days & 15 days exposed & Control 30 days & 30 days exposed \\
\hline gill & $0.63 \pm 0.01$ & $0.79 \pm 0.04(25.39 \%)$ & $0.45 \pm 0.08$ & $0.59 \pm 0.07(31.11 \%)$ \\
\hline liver & $0.58 \pm 0.06$ & $0.92 \pm 0.07(58.62 \%)$ & $0.49 \pm 0.05$ & $0.53 \pm 0.06(81.63 \%)$ \\
\hline kidney & $0.71 \pm 0.03$ & $0.88 \pm 0.08(23.94 \%)$ & $0.38 \pm 0.03$ & $0.54 \pm 0.10(42.10 \%)$ \\
\hline muscle & $0.84 \pm 0.02$ & $0.96 \pm .008(14.28 \%)$ & $0.56 \pm 0.13$ & $0.74 \pm 0.11(32.14 \%)$ \\
\hline
\end{tabular}

Data are means $\pm \mathrm{SD}$ of six individuals $(\mathrm{n}=6)$ values; significant at $p \leq 0.05$

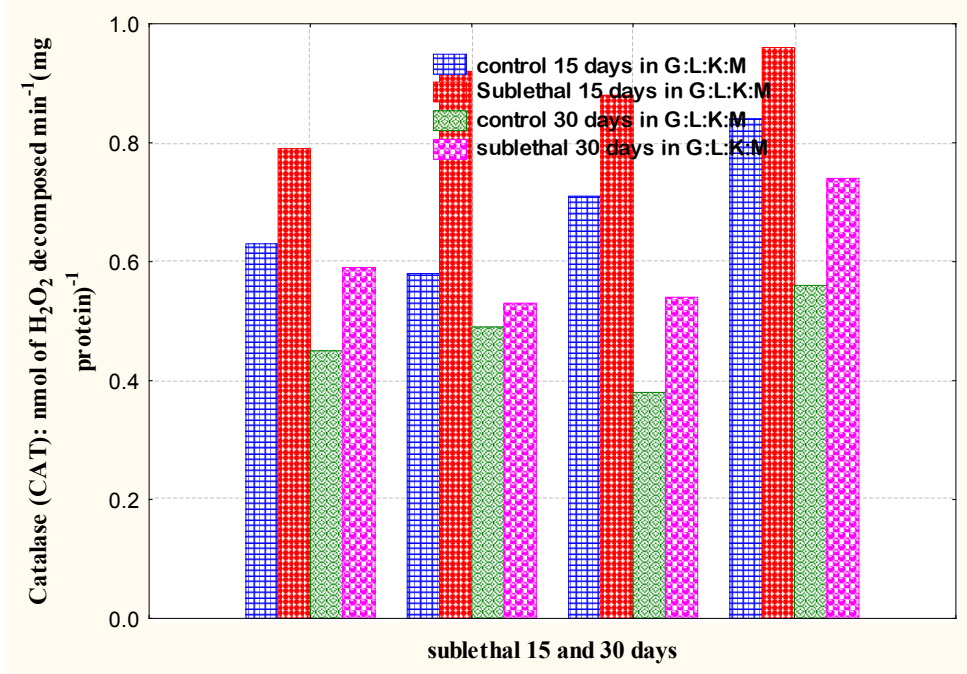

Figure 4. Activity of CAT in gill, liver, kidney and muscle of fish L.rohita exposed to sublethal concentration of chlorantraniliprole for 15 and 30 days. Bars represent means and vertical lines the SD of six individual observations

\subsubsection{Glutathione Peroxidase (Gpx)}

Activities of glutathione peroxidase were shown in Table 5 and figure 5.All the levels were compared with control and found to be significantly different, maximum increased in muscle (161.00\%) and minimum increased in gill,( $20.81 \%)$ for 15 days. In 30 days of exposure the maximum increased in (137.47\%) in muscle, minimum in (47.64\%) in kidney.

Table 5. Glutathione peroxidase (Gpx) activity (n mol of GSH oxidized min (mg protein) $)^{-1}$ ) in gill, liver, kidney and muscle of control and treated fish L.rohita

\begin{tabular}{|c|c|c|c|c|}
\hline Tissues & Control 15days & 15days exposed & Control 30 days & exposed 30 days \\
\hline gill & $149.39 \pm 3.54$ & $152.50 \pm 6.60(20.81 \%)$ & $102.54 \pm 0.04$ & $115.83 \pm 3.87(129.60)$ \\
\hline liver & $118.26 \pm 2.11$ & $126.81 \pm 5.31(72.29 \%)$ & $108.29 \pm 0.02$ & $118.17 \pm 4.88(91.23)$ \\
\hline kidney & $136.57 \pm 4.32$ & $157.83 \pm 10.21(15.56 \%)$ & $119.63 \pm 0.04$ & $125.33 \pm 6.80(47.64)$ \\
\hline muscle & $152.31 \pm 2.78$ & $161.00 \pm 8.46(57.05 \%)$ & $121.84 \pm 0.03$ & $138.59 \pm 18.00(137.47)$ \\
\hline
\end{tabular}

Data are means $\pm \mathrm{SD}$ of six individuals $(\mathrm{n}=6)$ values; significant at $p \leq 0.05$ 


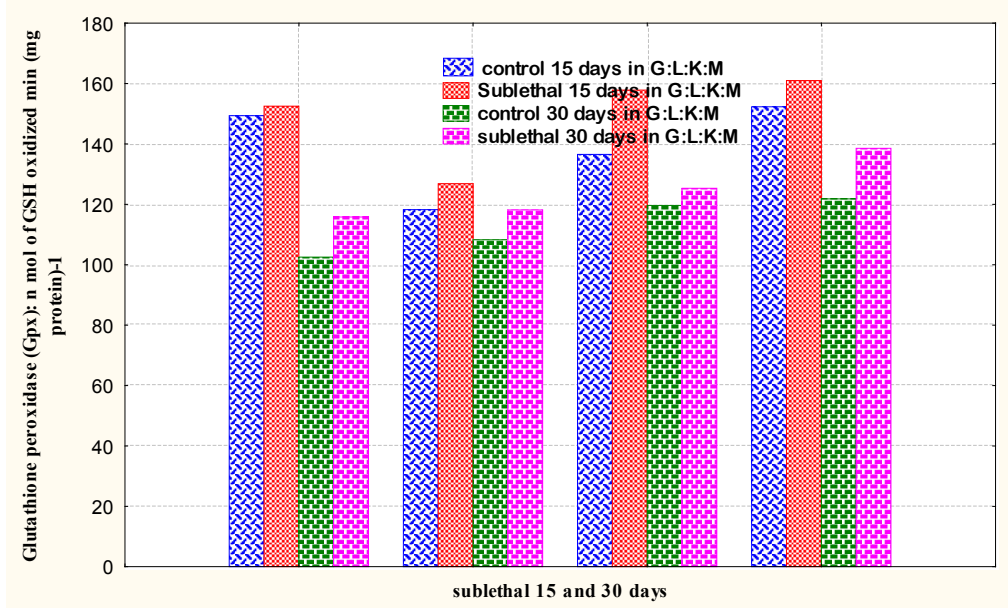

Figure 5. Activity of Gpx in gill, liver, kidney and muscle of fish L.rohita exposed to sublethal concentration of chlorantraniliprole for 15 and 30 days. Bars represent means and vertical lines the SD of six individual observations

\subsubsection{Lipid Peroxidation (LPO)}

Levels of malondialdehyde (MDA) lipid peroxidation were shown in Table 6; concurrent with earlier results, a significant increase in lipid peroxidation was depicted in all tissues of pesticide treated fish when compared with control. Elevated lipid peroxidation levels were observed $(83.95 \%, 36.58 \%)$ in liver and gill for 15 days, but when compared with 30 days treated tissues the MDA levels (figure 6) were much more higher $(88.20 \%, 72.63 \%, 61.16 \%)$ rise in liver, muscle and gill tissues.

\subsubsection{Glutathione S-Transferase (GST)}

Activities of GST in fish L.rohita were shown in Table 7. In liver initially (35.57\%) at 15 days of exposure, but in 30 days of exposure; showed increased in liver (99.30\%).After 15 days and 30 days of exposure, the fish showed a significant increase in GST activity in all tissues relation to the controls (figure 7).

Table 6. Lipid peroxidation (LPO) levels (nmol of malonaldehyde formed (mg of protein) ${ }^{-1}$ ) in gill, liver, kidney and muscle of control and treated fish L.rohita

\begin{tabular}{|c|c|c|c|c|}
\hline Tissues & Control 15days & 15days exposed & Control 30days & 30 days exposed \\
\hline gill & $0.492 \pm 0.03$ & $0.510 \pm 0.04(36.58)$ & $0.224 \pm .0 .02$ & $0.361 \pm 0.09(61.16)$ \\
\hline liver & $0.324 \pm 0.05$ & $0.596 \pm 0.09(83.95)$ & $0.212 \pm 0.07$ & $0.399 \pm 0.09(88.20)$ \\
\hline kidney & $0.521 \pm 0.03$ & $0.675 \pm 0.08(29.35)$ & $0.249 \pm 0.05$ & $0.365 \pm 0.07(46.58)$ \\
\hline muscle & $0.497 \pm 0.08$ & $0.648 \pm 0.07(30.38)$ & $0.296 \pm 0.06$ & $0.511 \pm 0.07(72.63)$ \\
\hline
\end{tabular}

Data are means $\pm \mathrm{SD}$ of six individuals $(\mathrm{n}=6)$ values; significant at $p \leq 0.05$

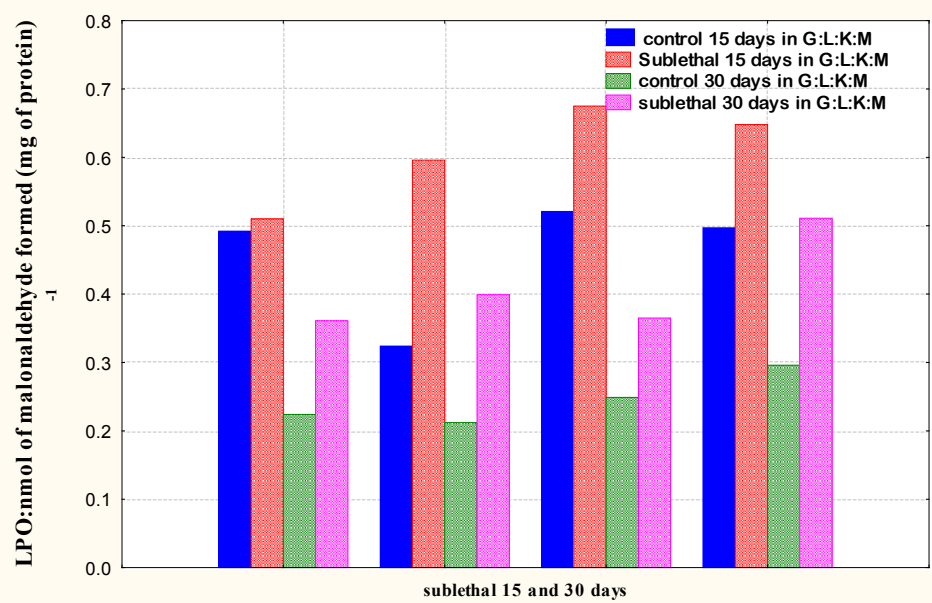

Figure 6. Levels of LPO in gill, liver, kidney and muscle of fish L.rohita exposed to sublethal concentration of chlorantraniliprole for 15 and 30 days. Bars represent means and vertical lines the SD of six individual observations 
Table 7. GST activity levels ( $\mathrm{U}$ mol of chloro -2, 4-dinitro-benzene (CDNB) conjugated formed $\mathrm{min}^{-1}$ of (mg of protein ${ }^{-1}$ ) in gill, liver, kidney and muscle of control and treated fish L.rohita

\begin{tabular}{|c|c|c|c|c|}
\hline Tissues & Control 15 days & 15 days exposed & Control 15 days & 30 days exposed \\
\hline gill & $214.59 \pm 0.02$ & $250.67 \pm 10.71(16.81)$ & $152.29 \pm 54.1$ & $186.33 \pm 9.31(22.35)$ \\
\hline liver & $198.41 \pm 0.03$ & $269.00 \pm 9.92(35.57)$ & $147.82 \pm 37.22$ & $162.50 \pm 7.31(99.30)$ \\
\hline kidney & $236.79 \pm 0.04$ & $267.83 \pm 4.17(31.04)$ & $139.22 \pm 16.25$ & $194.83 \pm 11.20(39.94)$ \\
\hline muscle & $242.52 \pm 0.25$ & $253.00 \pm 11.64(39.66)$ & $152.64 \pm 6.15$ & $166.00 \pm 13.68(87.52)$ \\
\hline
\end{tabular}

Data are means $\pm \mathrm{SD}$ of six individuals $(\mathrm{n}=6)$ values; significant at $p \leq 0.05$

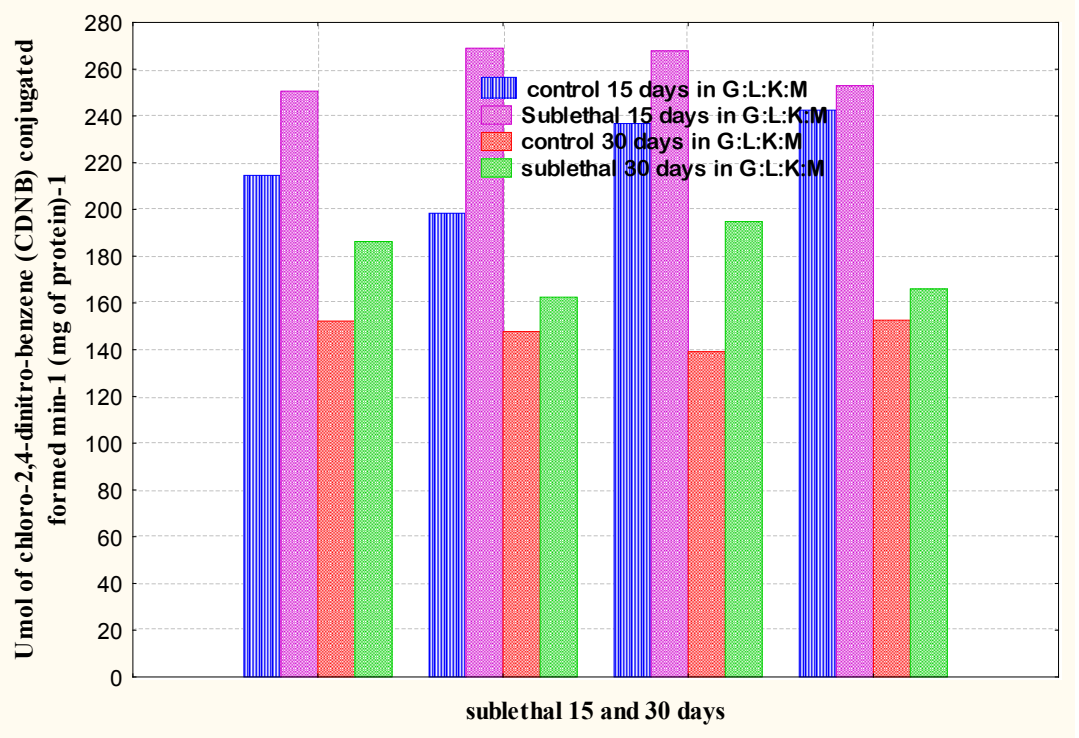

Figure 7. Activity of GST in gill, liver, kidney and muscle of fish L.rohita exposed to sublethal concentration of chlorantraniliprole for 15 and 30 days. Bars represent means and vertical lines the SD of six individual observations

\section{Discussion}

\subsection{Biochemical Analysis}

Biochemical changes induced by pesticide stress due to disturbed metabolism, even though, the pesticides have their own target site of action; most of them are metabolic depressors. They affect the activity of biomolecules such as proteins, carbohydrates and lipids. Proteins are indeed of primary and paramount importance in the living world not only because of their peculiars but also because of the fact that they appear to confer their biological specificity among various type of cells. Hence, the protein content of the cell considered to be an important tool for the evaluation of physical standards. The tissue protein is metabolized to produce glucose by the process of gluconeogenesis and it is utilized for energy production under pesticide stress condition [32]. The protein content is decreased due to chlorantraniliprole stress may be attributed to the utilization of amino acids in the various catabolic reactions. The results of the present study as presented in Table 1 and 2, the protein content of the various tissues like liver, kidney, gills, and muscle decreased by $(41 \%, 37 \%, 63 \%$, and $50 \%)$ respectively, at 15 and 30 days of exposure, as compared with control.

Amino acid content in the liver, kidney, gills, muscle showed a continuous decrease as the pesticide concentration was increased (Table 1,2 and figure 1,2)). The maximum reduction of amino acid content in kidney, liver, gills, and muscle of pesticide exposed fish were $(60 \%, 63 \%, 62 \%$, and $51 \%$ ) respectively at sublethal concentration for 15 and 30 days. The initial increase in free amino acids in tissues and later their sudden decline shows that these are utilized in the glycogenesis to compensate the energy demand under chemical stress. Thus the pesticides intoxification has disturbed the normal functioning of cells with the resultant alterations in the fundamental biochemical mechanisms in fish. This would in turn result in the mortality of fish on chronic exposure to the pesticide [33]. The glycogen content of liver, gill, kidney, and muscle tissues showed a decreasing trend as pesticide concentration increased (Table 1and 2). Depletion of glycogen in the tissues is indication of typical stress response in fish challenged with pesticides. A fall in glycogen levels indicates its rapid utilization to meet the enhanced energy demands in pesticide treated animals through glycolysis or hexose monophosphate pathway [34]; 
Glycogen depletion in liver and muscles after toxic stress has been reported in several studies with aquatic animals [35], The fish after exposure to two sublethal concentrations of chlorantraniliprole showed over all decrease in the content of glycogen into all the fish organs. The maximum decrease observed in liver and muscle, slight changes were recorded in kidney and gills. Among the biochemical profiles plasma glucose has been extensively used as a parameter to study stress and also used as a sensitive indicator of environmental stress in fish [36].The decrease level of glucose during sublethal treatments may be due to hypoxic condition caused by the toxicant, which reflects an excess utilization of stored carbohydrates during the experimental period. These results are accordance with the finding of [37].

The lipid content of liver, kidney, gills, and muscle showed decreased (Table 1, 2 and figure 1,2).In the low availability of carbohydrates, lipids serve as source of energy for supporting physiological functions of the body. The decline in the lipid content due to be the utilization of lipids for meeting the energy demand under the pesticide stress.

\subsection{Antioxidant Enzymes}

The results in the present study reveal significant rise in CAT, SOD, GST, Gpx, and LPO activity in all tissues of chlorantraniliprole treated fish compared to control fish. Similar studies have shown that an increase in the activity of SOD by [38], dose dependent response.

In this study significant rise in Catalase (CAT) activity in almost all tissues of chlorantraniliprole treated fish, when compared with controls. The maintenance of catalase activity observed in this study throught all the experimental time is congruent with the findings reported by[39].It has also been reported that lower concentration of endosulfan increase the CAT activity in Oncorhynchus mykiss, while the higher concentrations reduce the activity by[40]. The differences in catalase activity can be explained by the functions of these tissues.Thus,liver actively performs biosynthetic and detoxifying activities, which needs extensive energy supply provided by oxidative metabolism[41,42].

The enzymes such as GST, Gpx and SOD were also altered in all tissues. Similar results reported in O.mykiss due to [43]. Although the reasons for such effect of chlorantraniliprole are not understood at present, it is likely that the chemicals might be interacting primarily with tissues, resulting in rise or fall enzyme activities by increased reactive oxygen radicals as results of stress condition in the fishes. The superoxide dismutase (SOD) activity in the liver of $L$. rohita after chlorantraniliprole exposure was higher compared with the control (Table 4). There was a significant $(\mathrm{P}<0.05)$ increase in SOD activity with increase in the concentration of insecticide chlorantraniliprole and a $2^{\text {nd }}$ fold increase was noticed for 30 days. Increase in SOD activity compares well with increase in LPO and SOD is vital for fish because the induction in the SOD enzyme activity is considered as a first defense mechanism against oxidative stress [43], SOD and CAT are reported as the key enzymes which condense ROS formed during bio-activation of xenobiotics in the hepatic tissue. It has also been reported that the long term treatment with OP causes gradual depletion of SOD, Gpx, and GST or leads an increase of ADS[44]. The activities of the enzymes usually increase as an adaptive response to free radical overload. An increase in the SOD activity indicates an increase of $\mathrm{O} 2$ production and similar increase in SOD isomers in the liver of Leuciscus cephalus were reported as a result of pollution [45]. The increased SOD and CAT levels induced by chlorantraniliprole in $L$. rohita indicate an elevated antioxidant status attempting to neutralize the impact of the Reactive oxygen species (ROS). This result supported the statement [46, 40], SOD is responsible for the dismutation of the superoxide anion radical to $\mathrm{H}_{2} \mathrm{O}_{2}$, which is detoxified by both CAT and GPx activity. Due to the inhibitory effects on oxyradical formation, the SOD-CAT system provides the first defense line against oxygen toxicity [47].

The GPx levels were increased observed in the present study. (Table, figure2)The activity response is similar to that of catalase as both leads to the detoxification of product formed due to LPO action. Glutathione peroxidase (GPx) is important in the prevention of cell damage by oxidants. GPx being an antioxidant enzyme removes precursors of free oxygen radicals and is necessary for the conversion of hydrogen peroxide to molecular oxygen and water. GPx reduces reactive oxygen species (ROS) and intervene in hydrogen peroxide detoxification, leading to GPx formation of their corresponding alcohols or water. Thus, GPx is considered to play an important role in protecting membranes from damage due to LPO [48].

Glutathione S-transferase (GST) is a group of multifunctional enzyme involved in biotransformation and detoxification of xenobiotics [49].The increased GST activity in liver was observed in the present study after exposure to sublethal concentration of chlorantraniliprole suggests the increase in detoxification processes in Labeo rohita. GST has been reported as a biomarker for assessing the environmental impact of organic xenobiotics generating oxidative stress [50]. The GST was more active in hepatic tissue than in white muscle and gill, which indicates the effective role of liver in xenobiotic detoxification [51]. Typical reaction during this process is peroxidative damage to unsaturated fatty acids, which are consistently used as biomarkers of effect [52]. The increased lipid peroxidation in the present study $[53,54]$ suggested that the ROS induced oxidative damage can be one of the main toxic effects of chlorantraniliprole. It has been reported that LPO may be induced by a variety of environmental pollutants [55-57].

\section{Conclusion}

Our observations led us conclude that the sublethal concentration of chlorantraniliprole pesticide effects on the levels of proteins, glycogen, free amino acids, and total lipids. 
In the low availability of carbohydrates, lipids serve as source of energy for supporting physiological functions of the body. The decline in the lipid content due to be the utilization of lipids for meeting the energy demand under the pesticide stress. The results showed that the increased Antioxidant enzymes like; Superoxide dismutase (SOD), catalase (CAT), Gpx, GST, and lipid peroxidation (LPO) levels in liver, muscle, gills, and kidney compare to controls. Thus the results clearly evoke an imbalance in the cellular oxidative status by means of oxidative damage and decline in antioxidant defense due to chlorantraniliprole induced oxidative stress. In the presence of pesticide, an initial induction response in the antioxidant system may be followed by a reduction. Also, the results show that SOD, CAT and lipid peroxidation (LPO) activity levels in gills, liver, muscle, and kidney may be used as biomarkers for pollution monitoring and indicate that the activities of certain biomarkers in fish $L$. rohita are more sensitive to pesticides.

\section{REFERENCES}

[1] G.M.Christensen, and J.H. Tucker, (1977). Effects of selected waters toxicants on the in vitro activity of fish carbonic anhydrase. Rocz. Panstw. Zakl. High,28(6):595-600

[2] P.Palaniappan, S.L.R.M, Karthikeyan,(2009).Bioaccumulati on and depuration of chromium in the selected organs and whole body tissues of freshwater fish Cirrhinus mrigala individually and in binary solutions with nickel.J.Environ.Sci.21,229-236.

[3] D.Ghosh, S.Bhattacharya, Mazumder,(2006).Perturbations in the catfish immune responces by arsenic :organ and cell specific effects. Comp. Biochem. physiol. Part C.Comp.pharmacology.Toxicol,143;455-463.

[4] B.Kasprzyk-Hordern, R.M,Dinsdale,A.J.Guwy,(2009).Illicit drugs and pharmaceuticals in the environment- forensic applications of environmental data, Part 2: Pharmaceuticals as chemical markers of faecal water contamination.Environ.Pollut,157;1778-1786.

[5] B.Joseph, and S.J. Raj, (2010). Effect of curacron toxicity on the total serum protein content of Cyprinus carpio. Toxicol. Environ. Chem., 92: 1889-1893.

[6] Au, D.W.T.(2004).The application of histo-cytopathological biomarkers in marine pollution monitoring: a review. Marine Pollution Bulletin 48: 817-834.

[7] M.A.Ashraf, M.J.Maah, and I.Yusoff,(2012).Bioaccumulation of Heavy Metals in Fish Species Collected from Former Tin Mining Catchment, Int. J. Environ. Res.,6 (1), 209-218.

[8] Baby Joseph and S. Justin Raj,Review article;Impact of pesticide Toxicity on selected Biomarkers in Fishes, International journal of Zoological

Research,7(2):212-222,(2011).

[9] G.Sharma, and S. Singh,(2006). Assay of some blood parameters of the fish, Channa punctatus (Bloch.) after intoxication of Indofil. Bionotes, 8: 21-21.

[10] G. Sharma, and S. Singh,(2007). Effect of indofil toxicity on MCHC of Channa punctatus (Bloch.). J. Environ. Res. Dev., 1: $261-263$.

[11] Mohsen Khalili, Seyed Reza Khaleghi and Aliakbar Hedayati, (2012).Acute Toxicity Test of Two Pesticides Diazinon and Deltamethrin, on Swordtail Fish (Xiphophorus helleri). Global Veterinaria 8 (5): 541-545.

[12] A.Slaninova Smutna M, Modra H, Svobodova Z. Neuro Endocrinol Lett. (2009);30 Suppl 1:2-12.

[13] M. Dellali, N. El Bour, M. Mahmoud, A. Patricia, E. Mahmoudi, Ecolo. Indicators, 2010, 10,696.

[14] D.Webb,Gangnon,M.M.Rose,T,(2005).Metabolic enzyme activities in black bream,Acanthopagrus butcheri from the swan canning estuary, Western Austrilia.Comp.Biochem.physiol.Part C141,356-365.

[15] G.W.Winston, and R.T. Di Giulio, (1991). Prooxidant and antioxidant mechanisms in aquatic organisms. Aquat. Toxicol., 19: 137-161

[16] E.Maran, M. Fernández, P. Barbieri, G. Font and M. J. Ruiz,(2009).Effects of four carbamate compounds on antioxidant parameters. Ecotox. Environ. Saf., 72, 922-930

[17] B.Halliwell Gutteridge Jmc.. Oxygen toxicity, oxygen radicals, transition metals and disease. Biochem $J$ (1984). 219: 1-14.

[18] D.Schlenk, (1999). Necessity of defining biomarkers for use in ecological risk assessments. Mar.Pollut. Bull., 39, 48-53.

[19] A.P.Roberts, and J. T. Oris,(2004).Multiple biomarker response in rainbow trout during exposure to hexavalent chromium. Comp. Biochem. Physiol., Part C: Toxicol. Pharmacol., 138, 221-228.

[20] M.Ramesh, R.Srinivasan, M.Saravanan, (2009).Effect of atrazine(Herbicide) on blood parameters of common carp Cyprinus carpio (Actinopterygii:Cypriniformes).Afr.J.Envir on.Sci.Technol.3,453-458.

[21] American Public Health Association (APHA),(2005).American Water Works Association (AWWA) and Water Environment Federation (WEF), Washington DC ; USA.

[22] D.J.Finney, 1971. Probit analysis. Cambridge Univ. Press, Cambridge, 333 pp.

[23] O.H.Lowry, N.J. Rosebrough, Farr, A. L. \& Randall, R. J. 1951. Protein measurement with the Folin phenol reagent. The Journal of Biological Chemistry 193: 265-275.

[24] A.Kemp,Adrienne JM, Kits Van Hejningen,1954. A colorimetric method for the determination of glycogen in tissues. The Biochemical Journal (56): 640-648.

[25] S.Moore and Stein WH(1954). A modified ninhydrin reagent for the photometric determination of amino acids and related compounds: J.Biol.Chem., (221): 907

[26] J.Folch, M.Lees, and G.H.Sloane-Stanley, (1957).A Simple Method for the Isolation and Purification of Total Lipides from Animal Tissues, J. Biol. Chem. 226, 497-509.

[27] H.Luck ,1974, Methods in EnzymaticAnalysis, H U 
Bergmeyer (Ed.) AcademicPress, New York, p. 885.

[28] ZA.Placer, LL.Cushman, BC.Johnson,1966.Estimation of products of lipid peroxidation (asmalonyldialdhyde) in biochemical systems. Anal Biochem.16:359-64.

[29] Misra, H. P. and Fridovich, I. (1972) J. Biol. Chem., 247, 3170 .

[30] Pagila E, Donald Valentine, N. William, 1967. J. Lab. Clin. Med. 70:158-169

[31] Habig WH, Pabst MJ, Jakoby WB (1974) Glutathione S-transferases. The first enzymatic step in mercapturic acid formation. J Biol Chem 246:7130-7139

[32] M.Elumalai, M.P.Balasubramanian.Influence of naphthalene on esterase activity during vitellogenesis of marine edible crab, Scylla serrata, Bull.Env.Cont.Toxicol.62 (1999)743-748

[33] C. Thenmozhi, V. Vignesh, R. Thirumurugan, S. Arun. Impacts of malathion on mortality and biochemical changes of freshwater fish Labeo rohita,. Iran. J. Environ. Health. Sci. Eng., 2011, Vol. 8, No. 4, pp.

[34] Swarna kumari, R., Vijaya Kumar, M., and Tilak, K. S: Biochemical changes of total proteins and glycogen in the tissues of grass carp Ctenopharyngodon idella (Valenciennes), exposed to an organophosphate Nuvan $(76 \%$ EC) J.Aqua.Biol. 2008; 23; 159- 168.

[35] P.S.Bhavan,P. Geraldine. Alterations in concentrations of protein,carbohydrate,glycogen, free sugar, and lipid in the prawn Macrobrachium malcolmsonii on exposure to sublethal concentrations of Endosulfan,Pest.Biochem.Physiol,58;1997:89-101.

[36] Kavitha,S.C.,Malarvizhi,A.Senthil kumaran,S.,Ramesh,m.,(2010).Toxicological effects if arsenate exposure on hematological, biochemical and liver transaminases activity in an Indian major carp,Catla catla.Food Chem. Toxicol,48;2848-2854.

[37] R.Ghosh,R.V.Shrotri.Blood glucose and tissue glycogen interrelationship in Scylla serrata chronically exposed to thiodan,Environ.Biol13;(1992);233-237.

[38] Sharbidre AA, Metkari V, Patode P (2011) Effect of diazinon on acetylcholinesterase activity and lipid peroxidation of Poecilia reticulata. Res J Environ Toxicol 5:152-161

[39] Glusczak, L., Miron, D.S., Moraes, B.S., Simoes, R.R., Schetinger, M.R.C., Morsch, V.M.,Loro, V.L., 2007. Acute effects of glyphosate herbicide on metabolic and enzymatic parameters of silver catfish (Rhamdia quelen). Comp. Biochem.Physiol. C. 146, 519-524.

[40] Alves, S.R., Severino, P.C., lbbotson, D.P., de Silva, A.Z., Lopes, F.R.,Saenz, L.A. and Bainy, A.C. (2002). Effects of furadan in the brown mussel Perna perna and in the mangrove oyster Crassostrea rhizophorae. Mar. Environ. Res. $54(3-5): 241-245$.

[41] Oliveira M, Pacheco M, Santos MA. Organ specific antioxidant responses in golden grey mullet (Liza aurata) following a short-term exposure to phenanthrene. Sci Total Environ. 2008 Jun 15;396(1):70-78

[42] Vida Keramati, Shahla Jamili, Mahmoud Ramin. Effect of Diazinon on Catalase Antioxidant Enzyme Activity in Liver
Tissue of Rutilus rutilus. Journal of Fisheries and Aquatic Science, vol. 5, no. 5, pp. 368-376, (2010).

[43] A.Doyotte, c.cossu,39;1997,93-110;A. Doyotte, C. Cossu, M.C. Jacquin, et al., Aquat. Toxicol. 39 (1997) 93-110.

[44] Song SB, Xu Y, Zhou BS (2006) Effects of hexachlorobenzeneon antioxidant status of liver and brain of common carp(Cyprinus carpio). Chemosphere 65:699-706

[45] Lenartova, V., Holovska, K., Pedrajas, J.R., Martinez Lara, E., Peinado, J.,Lopez-Barea,-J., Rosival, I. and Kosuth, P. (1997). Antioxidant and detoxifying fish enzymes as biomarkers of river pollution. Biomarkers. 2:247-252.

[46] Gultekin F, Ozturk M, Akdogan M. The effect of organophosphate insecticide chlorpyrifos-ethyl on lipid peroxidation and antioxidant enzymes (in vitro). Arch Toxicol. (2000) ,74(9):533-8.

[47] Pandey, S., Parvez, S., Sayeed, 1., Haque, R., Bin-Hafeez, B., Raisuddin, S.(2003). Biomarkers of oxidative stress: a comparative study of river Yamuna fish -Wallago attu (B1. and Schn). Sci. Total Environ. 309(13):105-115.

[48] Oost, R., Beyer, J., Vermeulen, N.P.E. (2003). Fish bioaccumulation and biomarkers in environmental risk assessment: a review. Environ. Toxicol. Pharmacol. 13(2):57-149.

[49] Jokanović, M., 2001. Biotransformation of organophosphorus compounds. Toxicology 166, 139-160.

[50] Livingstone, D.R. (1998). The fate of organic xenobiotics in aquatic ecosystems: quantitative and qualitative differences in biotransformation by invertebrates and fish. Comp. Biochem. Physiol. A. 120(1):43-49.

[51] Basha, P.S. and Rani, A.U. (2003). Cadmium-induced antioxidant defense mechanism in freshwater teleost Oreochromis mossambicus (Tilapia). Ecotoxicol. Environ. Saf. 56(2):218-221.

[52] Sayeed I, Parvez S, Pandey S, Bin-Hafeez B, Haque $\mathrm{R}$, Raisuddin S. Oxidative stress biomarkers of exposure to deltamethrin in freshwater fish, Channa punctatus Bloch. Ecotoxicol Environ Saf.(2003),56(2):295-301.

[53] Ahmad, 1., Hamid, T., Fatima, M., Chand, H.S., Jain, S.K., Athar, M. and Raisuddin, S. (2000). Induction of hepatic antioxidants in freshwater catfish (Channa punctatus Bloch) is a biomarker of paper mill effluent exposure. Biochim. Biophys. Acta. 1523(1):37-48.

[54] Wilhelm-Filho, D., Torres, M.A., Tribbes, T.B., Pedrosa, R.C. and Soares,C.H.L. (2001). Influence of season and pollution on the antioxidantdefenses of the cichlid fish acara (Geophagus brasiliensis). Braz. J. Med.Biol. Res. 34(6):719-726.

[55] Oakes, K.D., McMaster, M.E. and Van der Kraak, G.J. (2004). Oxidative stress responses in long nose sucker (Catostomus catostomus) exposed to pulp and paper mill and municipal sewage effluents. Aquat. Toxicol. 67(3):255-271.

[56] Stanford moore andwilliam h. stein;a modified ninhydrin reagent for the photometric determination of amino acids and related compoundsj. biol. chem. 1954 211: 907-913.

[57] Sedigh Ahmadi, Mahvash Jafari2, Alireza Asgari, Maryam Salehi. Acute effect of diazinon on lipid peroxidation level 
and activities of antioxidant enzymes in rat spleen. Journal of

Kermanshah University of Medical Sciences. (2012); 16(1): 